\title{
Distribution and dispersal of early juvenile snails: effectiveness of intertidal microhabitats as refuges and food sources
}

\author{
Louis A. Gosselin***, Fu-Shiang Chia* \\ Department of Biological Sciences, University of Alberta, Edmonton, Alberta, Canada T6G 2E9 \\ and \\ Bamfield Marine Station, Bamfield, British Columbia, Canada V0R 1B0
}

\begin{abstract}
In Barkley Sound, British Columbia, Canada, newly hatched Nucella emarginata, a direct developing prosobranch gastropod, are almost exclusively located within 3 structurally complex microhabitats: the filamentous algae Cladophora columbiana, clusters of mussels Mytilus spp., and dense assemblages of the barnacle Semibalanus cariosus. When exposed to desiccation or predators for 4 to $5 \mathrm{~h}$, mortality of hatchlings located in these microhabitats ( 1.7 to $36 \%$ mortality) was considerably lower than for individuals on open surfaces (99 to $100 \%$ ). Also, food (prey species) in C. columbiana, mussel clusters, and $S$. cariosus microhabitats was more abundant but of similar energetic value to that on open rock surfaces. The microhabitats used by early juvenile $N$. emarginata thus provide the double advantage of a considerably reduced risk of mortalıty and abundant prey. The means by which hatchlings disperse after emerging from their egg capsules were established by laboratory observations and by deployment of collectors in the field. Hatchlings do not actively initiate dispersal by drifting in the water column. Crawling is the usual means of travelling from the capsule to protective microhabitats, with hatchling crawling speed averaging only $3.7 \mathrm{~mm} \mathrm{~min}^{-1}$ on smooth rock surfaces in the laboratory. The abundance and distribution of microhabitats that protect early juveniles could therefore be important determinants of the local abundance and distribution of $N$. emarginata populations. The use of protective microhabitats may be the key to survival through the vulnerable early juvenile period in many benthic marine organisms.
\end{abstract}

KEY WORDS: Mortality $\cdot$ Desiccation $\cdot$ Predation $\cdot$ Structural complexity $\cdot$ Drifting

\section{INTRODUCTION}

Although most aquatic organisms are highly vulnerable to mortality factors during the early juvenile period (Thorson 1966, Werner \& Gilliam 1984), actual levels of juvenile mortality can depend on microhabitat use. In lakes and streams, juvenile fish are often located in aquatic vegetation in which they suffer lower mortality by predation than in open water (Werner et al. 1983, Mittelbach 1984, Werner \& Hall 1988). In subtidal marine habitats, juvenile lobsters are associated with cobble and algae, which effectively reduce predation

\footnotetext{
- Present address: Department of Biology, Hong Kong University of Science and Technology, Clear Water Bay, Kowloon, Hong Kong

•-E-mail: lgosseli@usthk.ust.hk
}

risk (Herrnkind \& Butler 1986, Smith \& Herrnkind 1992, Wahle \& Steneck 1992). Most studies of microhabitat use by motile early juvenile aquatic animals have examined freshwater or subtidal marine organisms and have assumed predation to be the single most important cause of mortality. Inhabitants of the rocky intertidal zone are exposed to predators, but also to factors that do not occur in subtidal habitats or in most freshwater habitats, such as desiccation and pronounced daily variations in temperature. Desiccation is of particular interest because it is often the most severe and possibly the most widespread mortality factor in rocky intertidal habitats, and is often the physical factor most likely to cause mortality (Underwood 1979, Gosselin \& Chia 1995). Little information is available, however, on the effectiveness of rocky intertidal microhabitats as shelters from desiccation or predation for motile early juveniles. 
Since vulnerability generally scales inversely with body size, rapid growth during the early juvenile period is also considered to be an important strategy to reduce the likelihood of mortality by minimizing the time spent in the smallest, most vulnerable size classes (Vermeij 1978, 1987). If rapid growth is a priority, early juveniles should use microhabitats that offer the most favourable growth conditions. Hence, the distribution of motile early juveniles might be expected to correlate with food distribution, either in terms of abundance or value of food items to the juvenile.

The study of the distribution of early juvenile intertidal organisms can be difficult because early juveniles are often available only during a brief period as a result of seasonal spawning, and the exact time of their availability can be unpredictable. Due to an extended spawning season, however, newly hatched Nucella emarginata (Deshayes) (northern, cf. Palmer et al. 1990), an intertidal muricid gastropod, are available in the field for at least 3 to 7 months of the year (Spight 1982, Gosselin 1994). This gastropod has an extended geographic range along the northwestern coast of North America (Palmer 1984, 1985) and is often one of the most abundant gastropods in rocky intertidal habitats. The distribution of early juvenile $N$. emarginata in the field has not been determined, but hatchlings of an Atlantic species, Nucella lapillus, have been observed on the underside of rocks (Moore 1938) and in empty barnacle shells, but not on open rock surfaces (Feare 1970), suggesting a non-random distribution. Although newly hatched $N$. emarginata are most vulnerable to desiccation and predation by decapod crustaceans (Gosselin \& Chia 1995) and are unable to grow on energy reserves remaining from the egg capsule (Gosselin \& Chia 1994), it is not known whether the provision of shelter from mortality factors or the distribution of prey are important determinants of the distribution of early juveniles.

In muricid gastropods that hatch from benthic egg capsules as crawl-away juveniles, it is generally assumed that individuals remain within a short distance of the hatching site throughout their life (Spight 1974, Crothers 1985). Populations of these snails are believed to be mostly restricted to small areas of the shoreline (Spight 1974, 1975), and deep water or protected bays and inlets are expected to act as barriers to gene flow (Palmer 1984). These assumptions, however, are mostly based on studies of late juvenile and adult snails. The dispersal capabilities of small, newly hatched muricids have not been established. Other benthic marine invertebrates lacking a planktonic larval stage, such as certain bivalves, seastars, and snails, can disperse by drifting in the water column when very small (Sellmer 1967, Booth 1979, Martel \& Chia 1991a, Armonies 1992, 1994). In fact, some mol- luscs actively initiate this mode of dispersal (Sorlin 1988, Martel \& Chia 1991b). Two hatchling Nucella emarginata were caught in collectors suspended in the intertidal zone by Martel \& Chia (1991a), and N. emarginata hatchlings can produce mucus threads which considerably reduce sinking rates. Those results suggest that newly hatched $N$. emarginata may disperse by drifting in the water column. If so, this would have important implications regarding access to microhabitats, determining which microhabitats are within reach, and also regarding current assumptions on gene flow and population size and range.

The objectives of this study were therefore to: (1) identify the microhabitats in which early juvenile Nucella emarginata are located; (2) examine the effectiveness of early juvenile microhabitats as refuges from mortality factors (predation and desiccation) and as sources of prey; and (3) determine whether drifting or crawling is the main mode of dispersal after emerging from the egg capsule, and examine the implications of mode of dispersal for access to microhabitats during the early juvenile period and for population parameters.

\section{MATERIALS AND METHODS}

Study site and organism. Laboratory experiments were carried out at the Bamfield Marine Station, while field collections, observations and experiments were made at nearby intertidal sites in Barkley Sound, British Columbia, Canada (Fig. 1). Newly hatched Nucella emarginata used in the experiments described below were obtained by collecting ripe egg capsules (egg capsules that are unplugged but still contain fully developed snails that have not yet emerged) from Dixon Island and Wizard Islet (Fig. 1).

Distribution in the field. The distribution among microhabitats of Nucella emarginata throughout ontogeny was examined by sampling populations at 3 sites (Fig. 1): Ross Islets, a site protected from wave action, was sampled in July 1992 and again in September 1993; Wizard Islet, exposed to moderate wave action. was sampled in September 1991 and in August 1992 Cape Beale, exposed to full ocean surge, was sampled once in July 1992. For each sampling, quadrats $(25 \times$ $25 \mathrm{~cm}$ ) were positioned at $1 \mathrm{~m}$ intervals along transects running parallel to the shore in areas populated by $N$. emarginata. Sampling was carried out when hatchlings and juveniles were known to be present (Gosselin 1994). For each quadrat, the first step of the sampling procedure was to closely examine the enclosed area and collect all snails found on open surfaces. These observations were carried out without disturbing the habitat except for the careful displacement or removal 


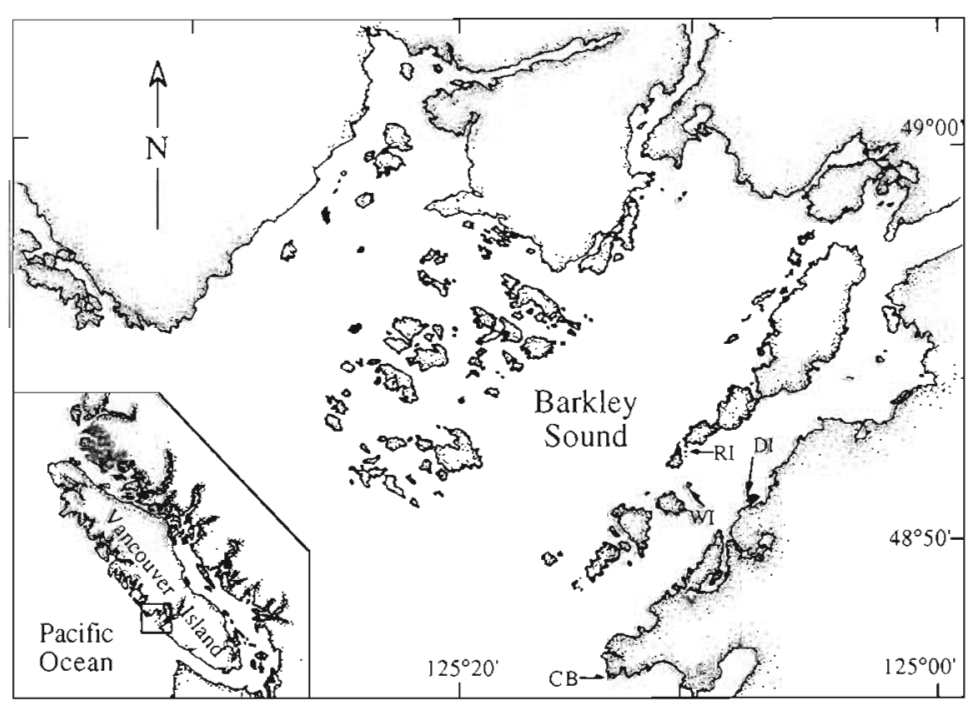

Fig. 1. Map of Barkley Sound, British Columbia, Canada, showing study sites. CB: Cape Beale; DI: Dixon Island; RI: Ross Islets; Wl: Wizard Islet

of fucoid algae, when present. Hatchlings were not found on fucoid fronds or holdfasts in preliminary samples or throughout the study. The second step consisted of closely inspecting small cracks and crevices and collecting samples of all other structurally complex microhabitats that might conceal a hatchling, within the same quadrat. At Ross and Wizard Islets, such microhabitats consisted mainly of sessile animals and algae: mussel clusters (Mytilus californianus and M. trossuIus), barnacles (mainly Semibalanus cariosus and Balanus glandula), and tufts of the filamentous algae Cladophora columbiana. Once fucoid algae were removed, these organisms together with bare rock totalled $-100 \%$ cover at tidal heights where N. emarginata was found. Although rock surfaces were irregular, there were few narrow cracks just wide enough for a newly hatched snail to enter. At Cape Beale, space was either available as bare rock or was covered by $M$. californianus, $S$. cariosus, $B$. glandula, or the gooseneck barnacle Pollicipes polymerus. C. columbiana was absent except for a few small tufts in protected crevices. When few of these organisms were present within a quadrat, all were collected. Often, however, a subsample of each was collected for a total volume of -0.75 to 11 . Samples were then returned to the laboratory and thoroughly washed in freshwater to extract all snails. Snails $\leq 3 \mathrm{~mm}$ were measured using the ocular micrometer of a dissecting microscope $( \pm 0.039 \mathrm{~mm})$; larger individuals were measured using a dial caliper $( \pm 0.1 \mathrm{~mm})$. The size and position of each snail, either on open surfaces or hidden within structurally complex microhabitats, was recorded.

Effectiveness of microhabitats as refuges. Because small Nucella emarginata were found almost exclu- sively within Cladophora columbiana, mussel clusters, and dense assemblages of the barnacle Semibalanus cariosus, the effectiveness of these microhabitats as shelters from desiccation and predation was examined. These microhabitats are hereafter referred to as Cladophora, mussel cluster, and Semibalanus microhabitats. Each microhabitat was reproduced on $8 \times 8 \times 1 \mathrm{~cm}$ shale rock plates, 3 replicate plates per microhabitat. The algae, mussels, and barnacle shells collected from the field to build the microhabitat plates were initially washed in freshwater to remove all snails that might be present. The plates were then prepared as follows so as to simulate the microhabitats as they occur in the field.

- Cladophora plates. Tufts of Cladophora columbiana were sewn onto the plates using $6 \mathrm{lb}$ (ca $2.7 \mathrm{~kg}$ ) monofilament line. The surface of each plate was thus covered by a dense mat of Cladophora with strands 5 to $6 \mathrm{~cm}$ high. Cladophora tufts were removed after each experimental run to recover the hatchlings; the 3 plates were prepared again with new tufts for each run.

- Semibalanus plates. Large shells of Semibalanus cariosus (11 to $34 \mathrm{~mm}$ basal diameter, 20 to $40 \mathrm{~mm}$ height) were attached in dense assemblages to each rock plate. Mainly the shells of dead barnacles were used, as live barnacles were inevitably killed when detached from intertidal rock surfaces. These large shells supported many smaller live barnacles (S. cariosus, Balanus glandula, and Chthamalus dalli), and care was taken to ensure that these stayed alive throughout the study. The body cavity of the large barnacles was cleaned, the opercular opening was plugged with hot melt glue and the base was levelled with sandpaper before being attached to the plate using epoxy glue. One or two large shells on each plate were left unplugged to simulate dead barnacles. Once prepared, these plates were placed in flowing seawater for $2 \mathrm{wk}$ before being used in experiments. After each experimental run, hatchlings were recovered by washing and spraying the shells with freshwater. The same plates were used in all experiments.

- Mussel cluster plates. Live Mytilus trossulus and M. californianus ( 5 to $65 \mathrm{~mm}$ shell length) were placed on rock plates in seawater for $8 \mathrm{~d}$ during which time they attached to the plates and to each other with byssal threads. During this period water flow was gradually increased, stimulating mussels to attach more strongly by producing more byssal threads. The resulting mussel clusters covered the plates with a layer of 4 to $5 \mathrm{~cm}$ depth. The clusters were detached after each run to recover the hatchlings, and new plates were prepared again for subsequent runs. 
- Open surface plates. A set of 3 bare plates was also included in each experimental run. These plates were placed in tanks with flowing seawater for $2 \mathrm{wk}$ prior to experimentation to allow the formation of a biofilm on the plate surfaces, as this might affect water retention and snail behaviour.

Protection from desiccation: The effectiveness of these 4 microhabitats as shelters from desiccation was determined in a field experiment at Wizard Islet on 11 September 1993. On that day, sunny, windy conditions coincided with an afternoon low tide, exposing intertidal organisms to high desiccation stress. Before leaving for the field, 8 to $10 \mathrm{~d}$ old hatchlings were inserted in the microhabitats, 20 hatchlings per plate. The plates were immersed in seawater for $45 \mathrm{~min}$ to allow the hatchlings to attach and crawl to a desired position. All plates were then placed in sealed containers and brought to the field. Open surface plates did not receive hatchlings until reaching the field site. Once in the field, the open surface plates were put in a tray with seawater and 20 hatchlings were placed on each plate. When these hatchlings had attached, the plates were gently removed from the water. All 12 plates ( 3 replicates $\times 4$ microhabitats) were then placed on a large mat $(\sim 0.75 \times 1 \mathrm{~m})$ of Cladophora columbiana growing on an area of flat, horizontal rock in the intertidal zone. The contact between the plates and the seawater absorbed in the C. columbiana mat helped maintain the plates at a temperature similar to that of nearby substrata. The site was $\sim 1.8 \mathrm{~m}$ above mean lower low water (MLLW), in an area supporting Nucella emarginata snails and egg capsules. After $4 \mathrm{~h}$ the plates were returned to the laboratory. Hatchlings were recovered from the microhabitats and placed in flowing seawater for $24 \mathrm{~h}$. Each snail was then examined under a dissecting microscope; snails not responding when the operculum was touched with a probe were recorded as dead.

Protection from predators: The effectiveness of these microhabitats as shelters from hermit crabs Pagurus spp. and shore crabs Hemigrapsus nudus, the main predators of hatchlings (Gosselin \& Chia 1995), was examined in the laboratory. Each plate was placed in a cage slightly larger than the plate itself (modified food containers, $9.5 \times 9.5 \times 6 \mathrm{~cm}$, with $610 \mu \mathrm{m}$ mesh screening). Rock plates were not used in the open surface treatment, the snails being placed directly on the bottom of the cage. Twenty hatchlings were added to each microhabitat, after which the sealed cages were immersed in seawater for 45 min before adding the predators. Each cage then received $1 P$. hirsutiusculus (5 to $6 \mathrm{~mm}$ claw length, CL), $1 P$ granosimanus $(5$ to 6 $\mathrm{mm} \mathrm{CL}$ ) and $1 \mathrm{H}$. nudus ( 6 to $7 \mathrm{~mm} \mathrm{CL}$ ). The cages were then placed in a 25010 -shaped 'surge tank' (length $=170 \mathrm{~cm}$, width $=65 \mathrm{~cm}$, height $=40 \mathrm{~cm}$ ) equipped with an electric motor attached to a paddle providing a continuous back-and-forth water motion to simulate hydrodynamic conditions in the intertidal zone at high tide. The surge-inducing paddle completed $\sim 5.5$ back-and-forth cycles min $^{-1}$, producing reversing water flows ranging in velocity from 0 to -15 $\mathrm{cm} \mathrm{s}^{-1}$. Cages were removed after $5 \mathrm{~h}$ and the contents were carefully examined for hatchlings and shell fragments. This experiment was carried out twice in July 1993, for a total sample size of 6 replicates per microhabitat.

Distribution of prey. To determine if early juvenile Nucella emarginata are located in microhabitats containing the best supply of prey, we examined the distribution of species (listed in Table 1) previously identified as hatchling prey (Gosselin \& Chia 1994) among the microhabitats occupied by hatchlings. On 12-15 August 1993, samples were collected at Dixon Island and Wizard Islet; each microhabitat was abundant at these sites, allowing comparisons of microhabitatspecific prey densities. At each site, 5 quadrats $(5 \times$ $5 \mathrm{~cm}$ ) haphazardly positioned over patches of each microhabitat were sampled. Prey present on open rock surfaces were counted on location. For Cladophora, mussel cluster, and Semibalanus microhabitats, contents of the quadrats were collected and examined in the laboratory. Given the preference of hatchlings for very small Mytilus spp. (Gosselin 1994), counts of Mytilus spp. were subdivided into 2 shell length size classes, 0.5 to 5 and 5.1 to $10 \mathrm{~mm}$. Mytilus spp. $>10 \mathrm{~mm}$ and Balanus glandula $>8 \mathrm{~mm}$ basal diameter were not counted because hatchlings are often unable to successfully attack such large prey (Palmer 1990, Gosselin pers. obs.).

Dispersal of hatchlings. Dispersal in the water Column: The prevalence of dispersal in the water column was examined in the field by quantifying recruitment to a collector (modified from Martel \& Chia 1991a) mimicking 2 microhabitats frequently containing newly hatched Nucella emarginata. The collector (Fig. 2) consisted of a $2.5 \mathrm{~cm}$ PVC plastic tubing frame supporting 2 pouches $(15 \times 15 \mathrm{~cm}, 2$ to $5 \mathrm{~cm}$ thick $)$ of $4.5 \mathrm{~mm}$ mesh screen at a height of $15 \mathrm{~cm}$ above the substratum. One pouch was filled with mussels (Mytilus trossulus and $M$. californianus, size range $=2$ to $50 \mathrm{~mm}$ shell length) that had been washed in freshwater, packed into the pouch, and placed in flowing seawater for $3 \mathrm{~d}$ to allow the production of new byssal threads. The other pouch was filled with Cladophora columbiana and 3 small rocks, enclosed to lend support and prevent the pouch from collapsing on the algae. The pouches were then tightly attached to the frame. To prevent snails from crawling up to the pouches from the substratum, copper wires $(\sim 3 \mathrm{~mm}$ diameter) were wrapped several times around each 

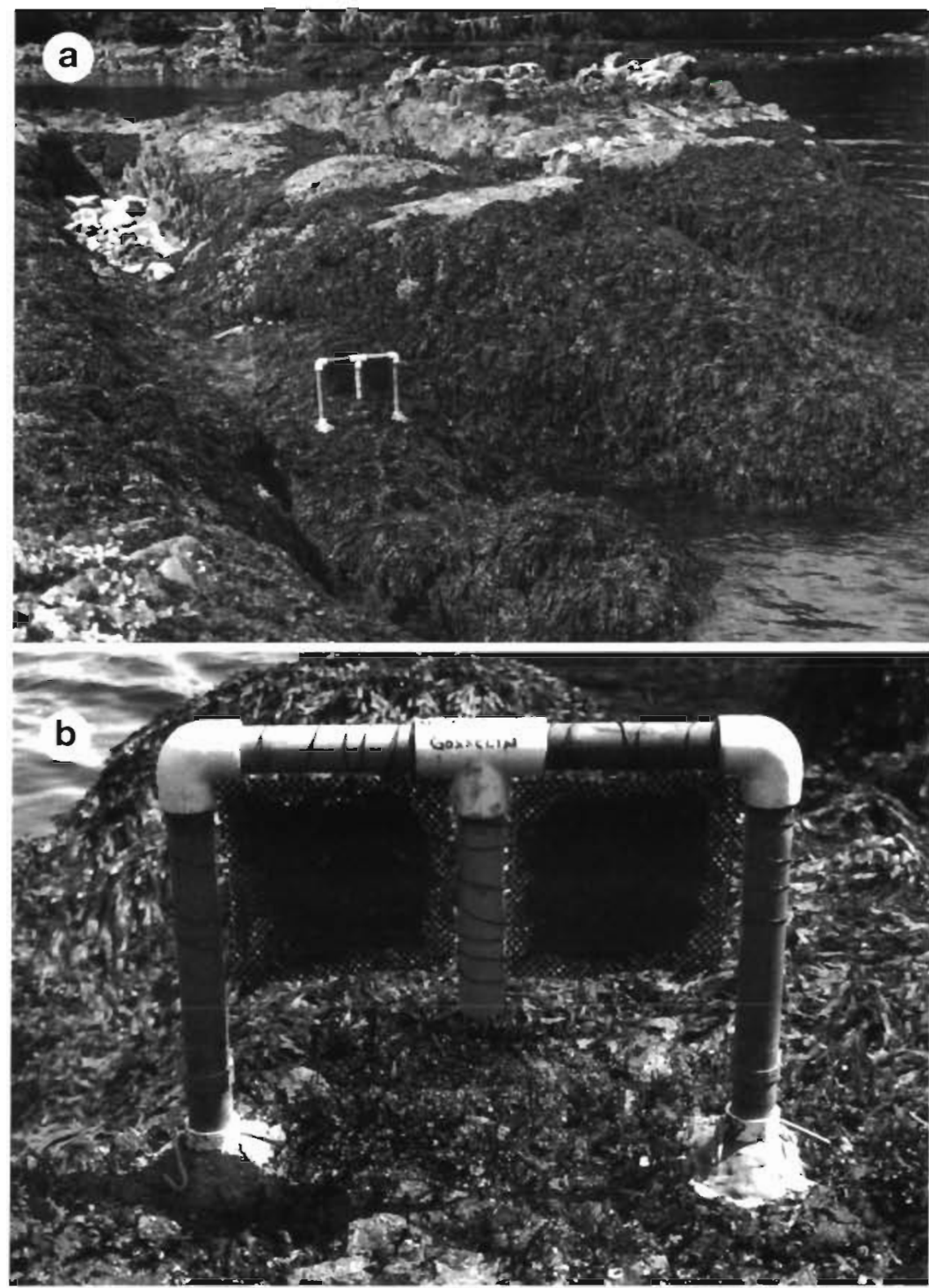

Fig. 2. (a) Collector installed in surge channel at Dixon Island, July 1993; (b) close-up view of collector

\section{RESULTS}

\section{Distribution in the field}

For each site and year sampled, the distribution of Nucella emarginata changed considerably as a function of body size (Fig. 3). Large individuals were mostly on open surfaces, while small $N$. emarginata were located within structurally complex microhabitats.

A close examination of several microhabitats revealed that snails $\leq 4 \mathrm{~mm}$ were almost exclusively located in the filamentous algae Cladophora columbiana, in mussel clusters (Mytilus spp.), and among dense assemblages of large Semibalanus cariosus. Snails $\leq 4 \mathrm{~mm}$ were not found on fronds or holdfasts of fucoid algae or in filamentous algae other than Cladophora, and they were rarely found among small barnacles (Balanus glandula, Chthamalus dalli and small $S$. cariosus) or among wellspaced large $S$. cariosus. Narrow cracks and crevices and the undersides of rocks and boulders were also examined, but these did not contain small Nucella emarginata.

Snail sizes were not distributed evenly among the 3 microhabitats in which juveniles were found (Fig. 4). The size-frequency distribution of snails in mussel clusters was not significantly different from that of snails among Semibalanus $(G=5.39, \mathrm{p}>0.99$, $\mathrm{df}=18 ; R \times C$ test of independence; Sokal \& Rohlf 1981). When size-frequencies of snails in Cladophora were included in the analysis, however, the test was highly significant $(G=110.2$, $p<0.0001$, df = 18); the size-frequency distribution of juveniles in Cladophora was more skewed towards the smallest size classes (mainly snails $\leq 3.5 \mathrm{~mm}$ shell length) than in mussel clusters and Semibalanus (Fig. 4)

Comparisons of total snail densities between microhabitats were not possible because quadrats rarely contained all microhabitats, an essential requirement for such comparisons due to the limited dispersal capability of hatchlings. Casual observations suggested that the abundance of hatchlings within microhabitat samples was highest in the proximity of egg capsules from which hatchlings had recently emerged.

\section{Effectiveness of microhabitats as refuges}

Protection from desiccation

When exposed to drying conditions in the intertidal zone for $4 \mathrm{~h}$, hatchling mortality differed significantly among microhabitats (Fig. 5a; Kruskal-Wallis test, $\left.H_{C}=9.551, \mathrm{p}<0.001, \mathrm{n}=12 ; \operatorname{Zar} 1984\right)$. None of the hatchlings on open surface plates survived the $4 \mathrm{~h}$ treatment, while only $1.7 \%$ of hatchlings in Cladophora died. Tufts of Cladophora retain water when emersed; in the field, naturally occurring Cladophora 


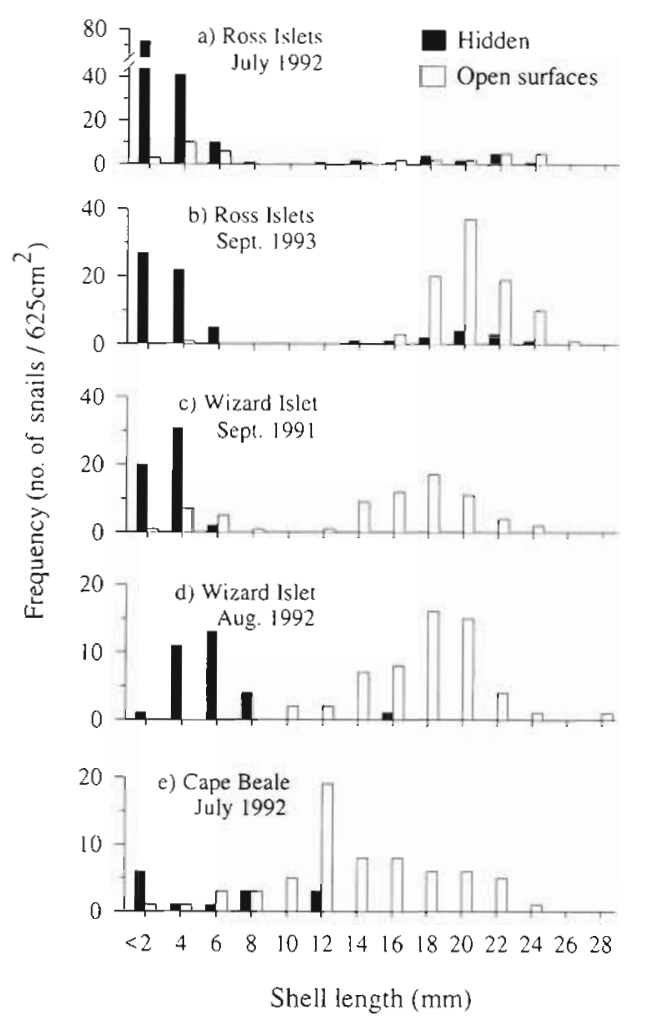

Fig. 3. Nucella emarginata. Size distribution of snails on open surfaces or located in structurally complex microhabitats (filamentous algae, mussel clusters, and assemblages of large barnacles). Each graph represents pooled data from all quadrats for the given site and date. Sample sizes: (a) 10 quadrats, (b) 10 quadrats, (c) 20 quadrats, (d) 20 quadrats, (e) 14 quadrats

were never observed to dry out at low tide, even on days when desiccating conditions were intense.

\section{Protection from predators}

Mortality of Nucella emarginata hatchlings exposed to 3 decapod predators for $5 \mathrm{~h}$ in the laboratory was also considerably lower in Cladophora, mussel clusters, and Semibalanus than on open surfaces (Fig. $5 b_{\text {; }}$ Kruskal-Wallis test, $H_{c}=18.696, \mathrm{p}<0.001, \mathrm{n}=24$ ). Hatchlings in the open surface treatment suffered $99.2 \%$ mortality, while in Cladophora mortality was less than $4 \%$.

\section{Distribution of prey}

Total prey densities were highest in Cladophora, Semibalanus, and mussel clusters (Table 1), with densities of up to 3105 prey per $100 \mathrm{~cm}^{2}$. Small Mytilus spp. and Lasaea spp. were by far the most abundant prey at the time of sampling.
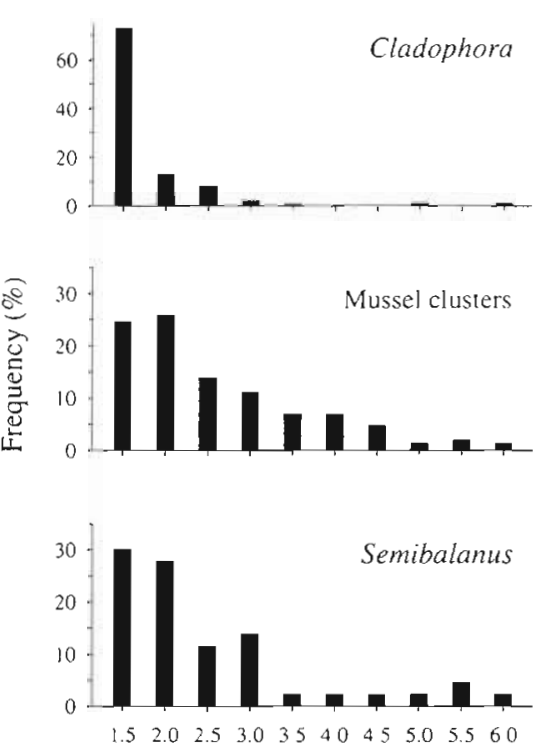

Shell length $(\mathrm{mm})$

Fig. 4. Nucella emarginata. Size distribution of small snails in structurally complex microhabitats: the filamentous algae Cladophora columbiana, mussel clusters (Mytilus californianus and $M$. trossulus), and assemblages of large barnacles Semibalanus cariosus. Pooled data from Wizard Islet 1991 and 1992 and Ross Islet 1992. Results are reported as a percentage of the total number of small snails in the same microhabitat. For example, $73 \%$ of snails $\leq 6 \mathrm{~mm}$ found in Cladophora were in the $\leq 1.5 \mathrm{~mm}$ size class, and $1.2 \%$ of Cladophora snails were in the 5.6 to $6.0 \mathrm{~mm}$ size class

Analysis of frequencies of the prey species using $R \times C$ tests of independence (Sokal \& Rohlf 1981) indicated that their relative frequency of occurrence was dependent upon microhabitat type, both at Dixon Island $(G=2378.12, \mathrm{p}<0.0001, \mathrm{df}=15)$ and at Wizard Islet $(G=668.94, \mathrm{p}<0.0001, \mathrm{df}=15)$. Prey species composition therefore differed significantly among microhabitats, Cladophora containing bivalve species in abundance but no barnacles, open rock surfaces mainly supporting small barnacles, and mussel clusters and Semibalanus containing some specimens of each prey species (Table 1).

\section{Dispersal of hatchlings}

Dispersal in the water column

No hatchlings recruited to the Cladophora or to the mussel cluster pouches of the collector on the 3 occasions when the collector was installed in the field. Water motion in the surge channel was nevertheless sufficient to suspend and transport small molluscs, as 100 to 300 juvenile Mytilus spp. (shell length $\leq 3 \mathrm{~mm}$ ) recruited to the 2 microhabitats on each occasion. 


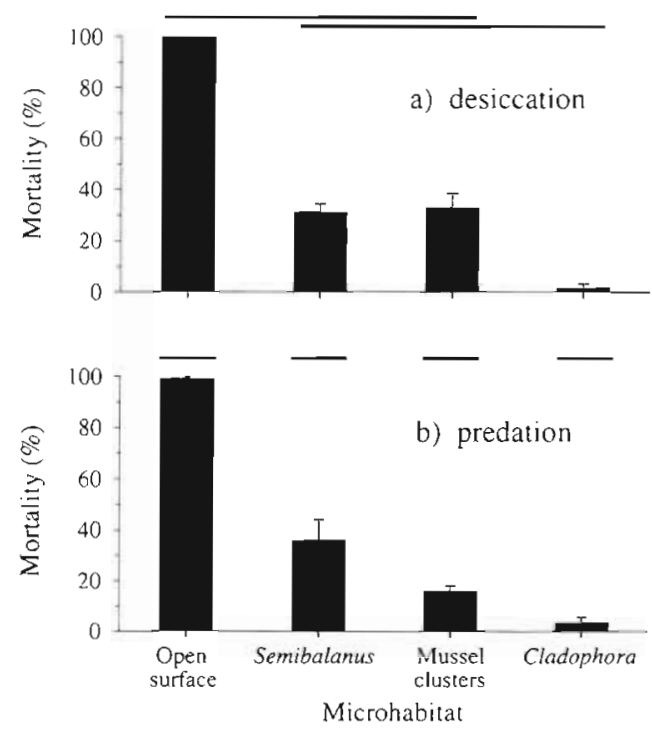

Fig. 5. Nucella emarginata. Mortality of newly hatched snails in 4 microhabitats: (a) after $4 \mathrm{~h}$ of exposure to desiccation in the intertidal zone ( $\mathrm{n}=3$ replicates of 20 hatchlings for each microhabitat); (b) after $5 \mathrm{~h}$ of exposure to 2 hermit crabs (1 Pagurus hirsutiusculus and 1 P. granosimanus) and 1 shore crab Hemigrapsus nudus $(\mathrm{n}=6$ replicates of 20 hatchlings for each microhabitat). Lines above the graph indicate values that are not significantly different (nonparametric multiple comparisons grouping at $\alpha=0.05$; Zar 1984). Error bars indicate standard errors

\section{Crawling speed}

During the crawling speed experiments, 34 hatchlings emerged from 4 capsules collected from separate clutches in the field. The average crawling speed $( \pm \mathrm{SD}$ ) during the first $30 \mathrm{~min}$ after leaving the egg capsule was $3.70 \pm 0.60 \mathrm{~mm} \mathrm{~min}^{-1}$, and ranged from 2.29 to $5.08 \mathrm{~mm} \mathrm{~min}^{-1}$.

\section{DISCUSSION}

\section{Distribution in the field}

The distribution of recently hatched Nucella emarginata contrasted sharply with that of adults. Virtually all hatchlings were located in structurally complex microhabitats, while adults often appeared conspicuously on open surfaces. A more subtle change in distribution across size classes was also apparent in Cladophora; this was the only microhabitat that contained only a narrow size-range $N$. emarginata, mostly corresponding to the sizes of recently hatched individuals (Fig. 4). Cladophora retains an upright, bushlike structure due to the turgor and slight calcification of the cells. As the snails grow, it is possible that this dense network increasingly hinders their movements until it is necessary to move to a different microhabitat.

During the study, a number of narrow cracks in the rock, wide enough for a hatchling to enter, were inspected with the use of a hammer and chisel. Such narrow cracks never contained early juvenile Nucella emarginata, and in fact usually contained very few macroscopic organisms, although Lasaea spp. were often present in such cracks at sites exposed to wave action. Similarly, Moore (1938) rarely found N. lapillus $<5 \mathrm{~mm}$ in small cracks and crevices, but found a number of $N$. lapillus $<2 \mathrm{~mm}$ among the Spirorbis borealis tubes, on the undersides of stones. The above distribution pattern of $N$. emarginata in Barkley Sound is therefore probably not typical of this region only. For instance, Spight (1975) rarely found $N$. emarginata or $N$. canaliculata $<5 \mathrm{~mm}$ shell length during almost $6 \mathrm{yr}$ of field work at several sites in Puget Sound, Washington, USA. Yet, he found new cohorts of snails $>5 \mathrm{~mm}$ each year, indicating that younger individuals must have been present. Given the results of the present study, it is possible that early juveniles of Puget Sound populations were also cryptically located, but that their microhabitats were not examined. Also, Feare (1970) reported that recently hatched $N$. lapillus in Yorkshire, England, avoided open surfaces. The association of early juveniles with structurally complex microhabitats may therefore be a common feature of Nucella spp.

Associations of small motile animals with structural refugia in benthic marine habitats can result from active microhabitat selection (Leber 1985, Herrnkind \& Butler 1986, Main 1987, Boudreau et al. 1990), differential mortality (Summerson \& Peterson 1984, Witman 1985, Aronson 1989), or possibly dislodgement and relocation of individuals on open surfaces by waves and currents (Kohn \& Leviten 1976). The proximate cause of the distribution of early juvenile Nucella emarginata is not known, and the identification of such cause was beyond the scope of this study. However, if hatchlings were to randomly move between shelters and open surfaces, it seems likely that they would rapidly be eliminated, thus favouring behaviours which restrict the distribution of hatchlings to structural refugia. Further study is needed to determine whether active microhabitat selection is the main cause of the observed distribution of early juvenile $N$. emarginata.

\section{Effectiveness of microhabitats as refuges and food sources}

Motile early juveniles of many benthic marine invertebrates are associated with structural refugia that are used only during a discrete period early in life, including 
lobsters (Barshaw \& Lavalli 1988, Wahle \& Steneck 1991. Smith \& Herrnkind 1992), mussels (Bayne 1964, Petersen 1984), nudibranchs (Sarver 1979), scallops (GarciaEsquivel \& Bricelj 1993), abalone (Hooker \& Morse 1985), and snails (Underwood 1976, Martel \& Chia 1991c, Sandt \& Stoner 1993, this study). Differential predation is often implicated as the ultimate cause of this association (Wilson et al. 1987, Martel \& Chia 1991c, Pohle et al. 1991, Smith \& Herrnkind 1992, Wahle \& Steneck 1992). The present study indicates that in the rocky intertidal zone, both predation and desiccation may act during alternate periods of the tidal cycle to cause high mortality of early juveniles not located in structural refugia. Most significant, however, was the magnitude of the difference in mortality over the short duration of the experiments: 99 to $100 \%$ of hatchlings on open surfaces died when exposed to desiccation or to predators for only 4 to $5 \mathrm{~h}$, while mortality of those in Cladophora, mussel clusters, or among Semibalanus was only 1.7 to $36 \%$. Given the high predator densities at most field sites, reaching in excess of 400 ind. $\mathrm{m}^{-2}$ (Gosselin \& Chia 1995), and the daily exposure of intertidal habitats to desiccation at low tide, it is therefore probable that complex microhabitats are essential for the survival of hatchling Nucella emarginata. Individuals that fail to reach these shelters soon after hatching, or that leave the shelters while still very small, incur a high risk of being killed within the following hours.

The microhabitats containing early juvenile Nucella emarginata provide the double advantage of a considerably reduced risk of mortality and abundant prey. Cladophora, mussel clusters and Semibalanus supported higher prey densities than open rock surfaces. Prey species content also differed between microhabitats, but this did not correspond to differences in prey value because Balanus glandula and Chthamalus dalli (mostly found on open surfaces) and Mytilus spp. (most abundant in Cladophora, mussel clusters, and among Semibalanus) are ranked similarly as the most favourable prey based on growth rates of hatchlings feeding on single prey species (Gosselin 1994). Thus, prey in complex microhabitats were more abundant but of similar value to prey on open rock surfaces.

The advantages provided by Cladophora (best protection against desiccation and predation, and highest density of prey) suggest this may be the most favourable microhabitat for newly hatched Nucella emarginata. However, the distribution of microhabitats in the field is patchy; given the limited motility of hatchling $N$. emarginata, Cladophora may not always be within reach or may not be encountered by certain hatchlings. Although mussel clusters and large Semibalanus are less favourable microhabitats than Cladophora, they nevertheless provide substantial protection and abundant prey.
Werner \& Gilliam (1984) suggested that small juvenile aquatic organisms should use habitats that minimize the ratio between mortality $(\mu)$ and growth $(g)$ (i.e. minimize $\mu / g$ ). Most newly hatched Nucella emarginata, however, will not feed during the first days after emerging from their egg capsule, even though feeding is essential for growth (Gosselin \& Chia 1994). The immediate need to avoid exposure to mortality factors might initially override activities necessary for growth. Patterns of habitat use would essentially be driven by $\mu$ until the individual's vulnerability had considerably decreased, as is usually the case when an organism reaches a larger size.

\section{Dispersal of hatchlings}

During our laboratory observations, undisturbed newly hatched Nucella emarginata did not raise a section of their foot, release mucous threads, or willingly detach from the substratum in response to turbulence or water flow, responses observed in other gastropod species that actively disperse in the water column (Martel \& Chia 1991b). When dislodged, however. $N$. emarginata hatchlings are capable of producing mucus threads which effectively reduce sinking rates (Martel \& Chia 1991a, Gosselin pers. obs.); this is undoubtedly an emergency measure used when they are dislodged by waves, predators, macroalgae, or debris and carried into the water column. Mucus threads, up to 160 times the shell length in Lacuna vincta (Martel \& Chia 1991b), constitute an effective means of gaining contact with algae, rock, or shells, thereby increasing a dislodged hatchling's chances of reattaching onto a nearby structure before being carried away. The $2 \mathrm{~N}$. emarginata hatchlings caught in off-bottom collectors by Martel \& Chia (1991a) at an exposed site in Barkley Sound indicated that dispersal in the water column does occur, but it is probably infrequent and we observed no such occurrence. Dispersal in the water column is unlikely at protected sites because surface conditions are usually at their calmest (Gosselin pers. obs.) during the period when most $N$. emarginata hatch (June to September; Gosselin 1994), but may occur at sites more directly exposed to ocean surge.

Crawling is therefore the usual means of travelling from the capsule to protective microhabitats. Hatchling crawling speed on a relatively smooth surface in the laboratory was only $-22 \mathrm{~cm} \mathrm{~h}^{-1}$. Linear dispersal in the field is undoubtedly much slower as a result of obstacles and surface irregularities. Hatchlings ceased crawling when emersed.

On the scale of an individual's lifetime, dispersal is therefore restricted to relatively short distances. Most individuals would indeed spend their entire life within 
a radius of a few meters of the position of the egg capsule from which they hatched. Hence, they would be dependent on the resources and environmental conditions existing within that small area. On an evolutionary time scale, however, dispersal may be greater than is currently assumed. Exchange of drifting hatchlings between adjacent groups of snails believed to be distinct populations may be sufficient to cause substantial gene flow. Since the prevalence of dislodgement and dispersal in the water column is likely to be proportional to wave exposure, the spatial ranges of Nucella emarginata populations may correspondingly expand over increasing gradients of wave exposure.

\section{CONCLUSION}

Gaining access to protective microhabitats may be the key to survival through the vulnerable early juvenile period. Given that hatchlings cannot survive the duration of a low tide when directly exposed to desiccation and are exposed to decapod predators at high tide (Gosselin \& Chia 1995, this study), it is essential that they reach a protective microhabitat shortly after emerging from their egg capsule.

The availability of microhabitats that can protect early juveniles may be important in determining whether Nucella emarginata can colonize a given site and set the upper limit of population abundance. The 3 microhabitats occupied by hatchlings in the field consisted of sessile organisms, 2 of which (Mytilus spp. and Semibalanus cariosus) can also be used as prey. Populations of $N$. emarginata will therefore be indirectly dependent on factors that affect the abundance and distribution of these sessile organisms (also see Leviten \& Kohn 1980). Since the dispersal capabilities of small $N$. emarginata are limited, the distribution of protective microhabitats (e.g. many small patches vs a few large patches) may be as important as total microhabitat abundance in determining the size and distribution of $N$. emarginata populations

Acknowledgements. We thank A. Kohn, T Rawlings, A. Shostak, H. Clifford, J. Holmes and an anonymous reviewer for providing helpful comments on previous versions of the manuscript. Thanks also to the director and staff of the Bamfield Marine Station for providing research facilities and support. This research was supported by an NSERC scholarship and a Sigurd Tveit Memorial scholarship to L.A.G., and by an NSERC operating grant to F.S.C.

\section{LITERATURE CITED}

Armonies W (1992) Migratory rhythms of drifting juvenile molluscs in tidal waters of the Wadden Sea. Mar Ecol Prog Ser 83:197-206
Armonies $W(1994)$ Turnover of postlarval bivalves in sediments of tidal flats in Königshafen (German Wadden Seas). Helgoländer Meeresunters 48:291-297

Aronson RB (1989) Brittlestar beds: low-predation anachronisms in the British Isles. Ecology 70:856-865

Barshaw DE, Lavalli KI (1988) Predation upon postlarval lobsters, Homarus americanus, by cunners, Tautogolabrus adspersus, and mud crabs, Neopanope sayi, on three different substrates: eelgrass, mud, and rocks. Mar Ecol Prog Ser 48:119-123

Bayne BL (1964) Primary and secondary settlement in Mytilus edulis L. (Mollusca). J Anim Ecol 33:513-523

Booth JD (1979) Common bivalve larvae from New Zealand Leptonacea. NZ J mar Freshwat Res 13:241-254

Boudreau B, Bourget E, Simard Y (1990) Benthic invertebrate larval response to substrate characteristics at settlement: shelter preferences of the American lobster Homarus americanus. Mar Biol 106:191-198

Crothers JH (1985) Dogwhelks: an introduction to the biology of Nucella lapillus (L.). Field Studies 6:291-360

Feare CJ (1970) Aspects of the ecology of an exposed shore population of dogwhelks Nucella lapillus (L.). Oecologia 5:1-18

Garcia-Esquivel Z, Bricelj VM (1993) Ontogenetic changes in microhabitat distribution of juvenile bay scallops, Argopecten irradians irradians (L.), in eelgrass beds, and their potential significance to early recruitment. Biol Bull 185 : $42-55$

Gosselin LA (1994) The ecology of early juvenile Nucella emarginata (Gastropoda, Prosobranchia): are hatchling snails simply small adults? Ph.D. dissertation, University of Alberta, Edmonton

Gosselin LA, Chia FS (1994) Feeding habits of newly hatched juveniles of an intertidal predatory gastropod, Nucella emarginata (Deshayes). J exp mar Biol Ecol 176:1-13

Gosselin LA. Chia FS (1995) Characterizing temperate rocky shores from the perspective of an early juvenile snail: the main threats to survival of newly hatched Nucella emarginata. Mar Biol 122:625-635

Herrnkind WF, Butler MJ IV (1986) Factors regulating postlarval settlement and juvenile microhabitat use by spiny lobsters, Panulirus argus. Mar Ecol Prog Ser 34:23-30

Hooker N, Morse DE (1985) Abalone: the emerging development of commercial cultivation in the United States. In: Huner JV, Brown EE (eds) Crustacean and mollusk cultivation in the United States. AVI Publishing Co, Connecticut

Kohn AJ, Leviten PJ (1976) Effect of habitat complexity on population density and species richness in tropical intertidal predatory gastropod assemblages. Oecologia 25: $199-210$

Leber KM (1985) The influence of predatory decapods, refuge, and microhabitat selection on seagrass communities. Ecology 66:1951-1964

Leviten PJ, Kohn AJ (1980) Microhabitat resource use, activity patterns, and episodic catastrophe: Conus on tropical intertidal reef rock benches. Ecol Monogr 50:55-75

Main KL (1987) Predator avoidance in seagrass meadows: prey behavior, microhabitat selection, and cryptic coloration. Ecology 68:170-180

Martel A, Chia FS (1991a) Drifting and dispersal of small bivalves and gastropods with direct development. J exp mar Biol Ecol 150:131-147

Martel A, Chia FS (1991b) Foot-raising behaviour and active participation during the initial phase of post-metamorphıc drifting in the gastropod Lacuna spp. Mar Ecol Prog Ser $72: 247-254$ 
Martel A, Chia FS (1991c) Oviposition, larval abundance, in situ larval growth and recruitment of the herbivorous gastropod Lacuna vincta in kelp canopies in Barkley Sound, Vancouver Island (British Columbia). Mar Biol 110: $237-247$

Mittelbach GG (1984) Predation and resource partitioning in two sunfishes (Centrarchidae). Ecology 65:499-513

Moore HB (1938) The biology of Purpura lapillus. Part III. Life history and relation to environmental factors. J mar biol Ass UK 23:67-74

Palmer AR (1984) Species cohesiveness and genetic control of shell colour and form in Thais emarginata (Prosobranchia, Muricacea); preliminary results. Malacologia $25: 477-491$

Palmer AR (1985) Genetic basis of shell variation in Thais emarginata (Prosobranchia, Muricacea). I. Banding in populations from Vancouver Island. Biol Bull 169:638-651

Palmer AR (1990) Predator size, prey size, and the scaling of vulnerability: hatchling gastropods vs barnacles. Ecology $71: 759-775$

Palmer AR, Gayron SD, Woodruff DS (1990) Reproductive, morphological, and genetic evidence for two cryptic species of Northeastern Pacific Nucella. Veliger 33:325-338

Petersen JH (1984) Larval settlement behavior in competing species: Mytilus californianus Conrad and $M$. edulis $L$. $\mathrm{J}$ exp mar Biol Ecol 82:147-159

Pohle DG, Bricelj VM, Garcia-Esquivel Z (1991) The eelgrass canopy: an above-bottom refuge from benthic predators for juvenile bay scallops Argopecten irradians. Mar Ecol Prog Ser 74:47-59

Sandt VJ, Stoner AW (1993) Ontogenetic shift in habitat by early juvenile queen conch, Strombus gigas: patterns and potential mechanisms. Fish Bull 91:516-525

Sarver DJ (1979) Recruitment and juvenile survival in the sea hare Aplysia juliana (Gastropoda: Opisthobranchia). Mar Biol 54:353-361

Sellmer GP (1967) Functional morphology and ecological life history of the gem clam, Gemma gemma (Eulamellibranchia: Veneridae). Malacologia 5:137-223

Smith KN, Herrnkind WF (1992) Predation on early juvenile spiny lobsters Panulirus argus (Latreille): influence of size and shelter. J exp mar Biol Ecol 157:3-18

Sokal RR, Rohlf FJ (1981) Biometry, 2nd edn. WH Freeman, New York

Sorlin T (1988) Floating behaviour in the tellinid bivalve Macoma balthica (L.). Oecologia 77:273-277

This article was presented by C. Levings (Senior Editorial Advisor), Vancouver, British Columbia, Canada
Spight TM (1974) Sizes of populations of a marine snail Ecology 55:712-729

Spight TM (1975) On a snail's chances of becoming a year old Oikos 26:9-14

Spight TM (1982) Population sizes of two marine snails with a changing food supply. J exp mar Biol Ecol 57:195-217

Summerson HC, Peterson CH (1984) Role of predation in organizing benthic communities of a temperate-zone seagrass bed. Mar Ecol Prog Ser 15:63-77

Thorson G (1966) Some factors influencing the recruitment and establishment of marine benthic communities. Neth J Sea Res 3:267-293

Underwood AJ (1976) Analysis of patterns of dispersion of intertidal prosobranch gastropods in relation to macroalgae and rock-pools. Oecologia 25:145-154

Underwood AJ (1979) The ecology of intertidal gastropods Adv mar Biol 16:111-210

Vermeij GJ (1978) Biogeography and adaptation. Patterns of marine life. Harvard University Press, Cambridge, MA

Vermeij GJ (1987) Evolution and escalation. An ecological history of life. Princeton University Press, Princeton, NJ

Wahle RA, Steneck RS (1991) Recruitment habitats and nursery grounds of the American lobster Homarus americanus: a demographic bottleneck? Mar Ecol Prog Ser 69:231-243

Wahle RA, Steneck RS (1992) Habitat restrictions in early benthic life: experiments on habitat selection and in situ predation with the American lobster. J exp mar Biol Ecol 157:91-114

Werner EE, Gilliam JF (1984) The ontogenetic niche and species interactions in size-structured populations. A Rev Ecol Syst 15:393-425

Werner EE, Gilliam JF, Hall DJ, Mittelbach GG (1983) An experimental test of the effects of predation risk on habitat use in fish. Ecology 64:1549-1555

Werner EE, Hall DJ (1988) Ontogenetic habitat shifts in bluegill: the foraging rate-predation risk trade-off. Ecology 69:1352-1366

Wilson KA, Able KW, Heck KL Jr (1987) Juvenile blue crab, Callinectes sapidus, survival: an evaluation of eelgrass, Zostera marina, as refuge. Fish Bull 85:53-58

Witman JD (1985) Refuges, biological disturbance, and rocky subtidal community structure in New England. Ecol Monogr 55:421-445

Zar JH (1984) Biostatistical analysis, 2nd edn. Prentice-Hall, Englewood Cliffs, NJ

Manuscript first received: February 27, 1995

Revised version accepted: July 13,1995 